\title{
ANALISYS OF THE INFLUENCE OF GLUE JOINTS ON THE MEASUREMENT OF PHYSICAL PROPERTIES OF STRUCTURAL ELEMENTS USING FIBER BRAGG GRATING
}

Tomasz Zieliński, Lukasz Zychowicz

Lublin University of Technology, Department of Electronics and Information Technology, Lublin, Poland

Abstract. The research presents the analysis of the influence of the glue connection on the measurement of elongation of stainless steel and aluminum samples by means of fiber Bragg grating (FBG) with uniform fibers used as a measuring transducer. Research indicates two possible factors affecting the deformation of the transmission spectrum obtained during elongation measurement. One of them is the type of adhesive that is used to make the connection between the fiber Bragg grating and the tested sample. The second possible factor is method of connection's execution. The need for research on glue connection resulted from the formation of defects mainly in the form of numerous side bands visible in the transmission spectrum during the measurement of elongations. The test results were presented in the form of graphs obtained on the basis of transmission characteristic.

Keywords: glue connections, fiber Bragg grating, elongation measurement, fiber sensor

\section{BADANIE WPLYWU POLĄCZEŃ KLEJOWYCH NA POMIAR WLAŚCIWOŚCI FIZYCZNYCH ELEMENTÓW KONSTRUKCYJNYCH ZA POMOCĄ ŚWIATLOWODOWEJ SIATKI BRAGGA}

Streszczenie. W pracy przedstawiono analizę wpływu połaczenia klejowego na pomiar wydtużenia próbek ze stali nierdzewnej i aluminium za pomoca światłowodowej siatki Bragga (FBG) o jednolitych włóknach wykorzystanej jako przetwornik pomiarowy. Badania wskazuja na dwa możliwe czynniki wptywajace na deformacje widma transmisyjnego otrzymywanego podczas pomiaru wydtuzenia. Jednym z nich jest rodzaj kleju jaki wykorzystuje się do wykonania połaczenia pomiędzy świattowodowa siatka Bragga, a badana próbka. Drugim możliwym czynnikiem jest sposób wykonania połaczenia. Potrzeba badań nad połaczeniem klejowym wynikła z powstawania defektów głównie $w$ formie licznych wstęg bocznych, widocznych na widmie transmisyjnym podczas pomiaru wydlużeń. Wyniki badań zostały przedstawione w formie wykresów uzyskanych na podstawie widm transmisyjnych.

Słowa kluczowe: połączenia klejowe, światłowodowa siatka Bragga, pomiar wydłużenia, światłowodowy czujnik

\section{Introduction}

Plenty of advantages of fiber optics mean that it is currently used in every field of technology, mainly as a medium for data transmission. Its features also allow it to be used as a sensor of physical quantities after creating periodic changes in its core. FBG produced in the fiber core as a measuring transducer is insensitive to changes in the electromagnetic field. It can be used in flammable and chemically aggressive environments. The small size and weight of FBG causes that in most cases the impact on the examined object is ignored $[3,5]$.

Using FBG as an elongation sensor requires attaching it to the tested element. The most popular method of attaching FBG to the tested element is gluing it, which brings a number of risks. They are related to the method of applying the adhesive or the selection of the adhesive itself. The paper presents transmission spectra obtained during the tests of elongation of stainless steel and aluminum samples using fiber Bragg grating attached to the samples by adhesive method. The presented research indicates a significant impact of the technique of attaching the measuring transducer to the sample on the transmission spectrum of the periodic structure.

\section{Measuring project}

The system from Figure 1 was used for the task and elongation measurement. To construct the presented measurement system an experimental system (allows to set specific tension values), furthermore a light source and spectrum analyzer was used. The white light from a light source goes to the FBG sensor. The sample (sensor) is stretched by a tensile force $F$ acting on arm $r_{1}$, caused by the weight $Q$ acting on arm $r_{2}$. The spectrum analyzer records the light that passes through a sensor under tensions. The deformation value $\varepsilon$ to which the sample undergoes (according to 1):

$$
\varepsilon=\frac{\frac{m \cdot g \cdot r_{2}}{r_{1} \cdot w \cdot s}}{E}
$$

where $m$ is the mass of weight, $g$ is the gravitational acceleration, $r_{2}$ is the length of the arm on which the force $Q$ acts. $Q$ is the gravitational force, $r_{l}$ is the length of the arm, which is affected by the force $F, w$ and $s$ are the thickness and width of the tested sample in the test location, while $E$ is the Young's modulus for the material from which the sample is made [4].
The samples had cross-sections of $5 \mathrm{~mm}^{2}$ and $10 \mathrm{~mm}^{2}$. The Young's modulus chosen for calculations for stainless steel is $210 \mathrm{GPa}$, while for aluminum samples $E=70 \mathrm{GPa}$ was chosen. The range of tensile forces affecting on the samples is from 50 to $310 \mathrm{~N}$. During the tests, the temperature in the laboratory ranged between 21 and $22^{\circ} \mathrm{C}$.

For testing, the method of completely embedding the transducer in the adhesive was chosen, which allowed for the largest possible contact surface of FBG to sample. The fiber Bragg grating was attached with a two-component epoxy adhesive with Young's modulus $E=1.77 \mathrm{GPa}$. The measuring transducer was embedded in glue for a length of $25 \mathrm{~mm}$ and a bonding width of $4 \mathrm{~mm}$.

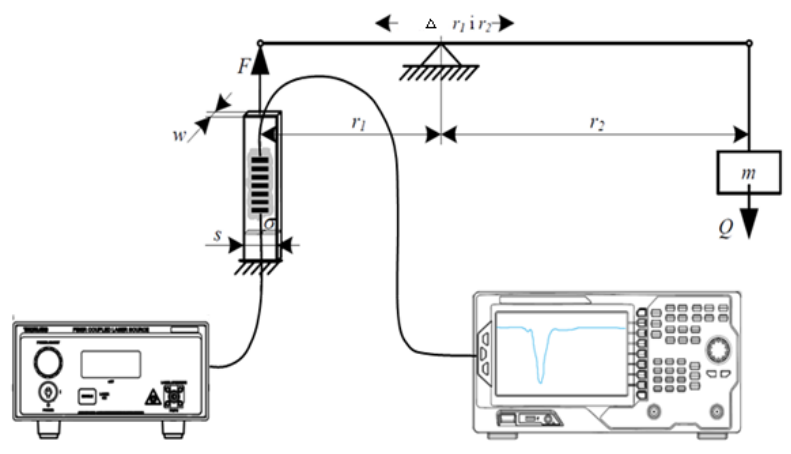

Fig. 1. Diagram of the measuring system

\section{Spectrums}

Figures from 2 to 9 show the transmission characteristics of power $P$ from the wavelength $\triangle$ of the FBG for individual forces.

Transmission spectra are the result of tests carried out on stainless steel and aluminum samples. Analyzing the charts, it can be concluded that the quantity and power of side bands created during the stretching of the samples was much higher in the case of aluminum samples. In Figures 2 and 3 it can be clearly observed that the power of the main peak is divided into the power of the main peak and the power of the side peaks resulting from the stretching of the sample. The phenomenon of the frequent occurrence of side bands in the case of aluminum can be explained by its smaller Young's modulus compared to steel, and thus a greater deformation when applying the same tensile force. 
However, as the stress increases, the number of side peaks increases for all transmission spectra of the samples tested. It can be concluded that the glue or the gluing method is responsible for these deformations.

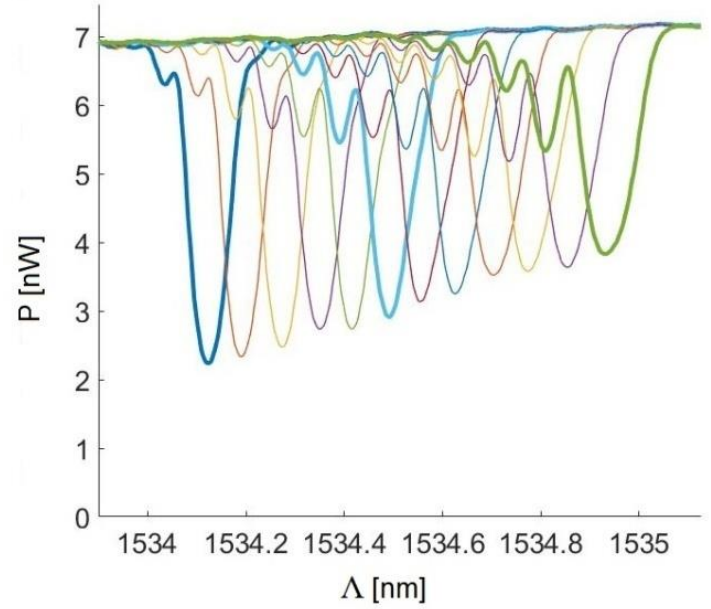

Fig. 2. Transmission characteristics obtained during the experimental research of the aluminum $5 \mathrm{~mm}^{2}$ cross-section sample

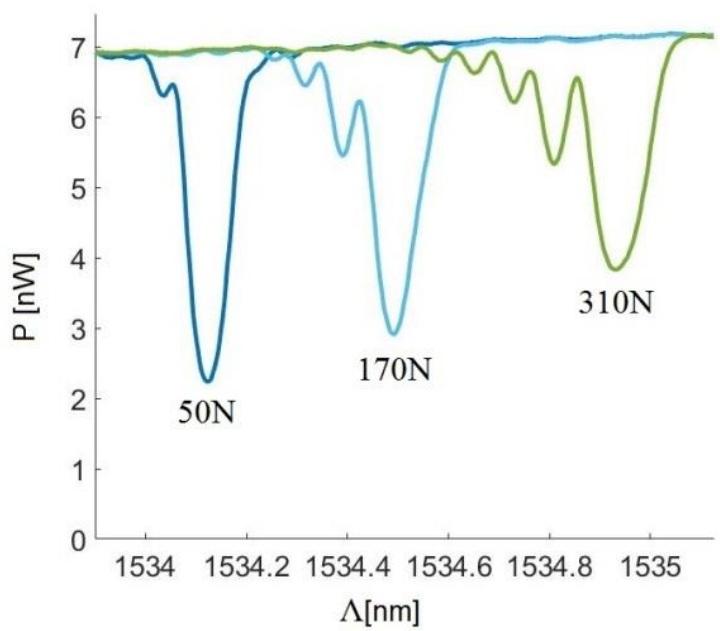

Fig. 3. Selected transmission characteristics obtained during the experimental research of the aluminum $5 \mathrm{~mm}^{2}$ cross-section sample

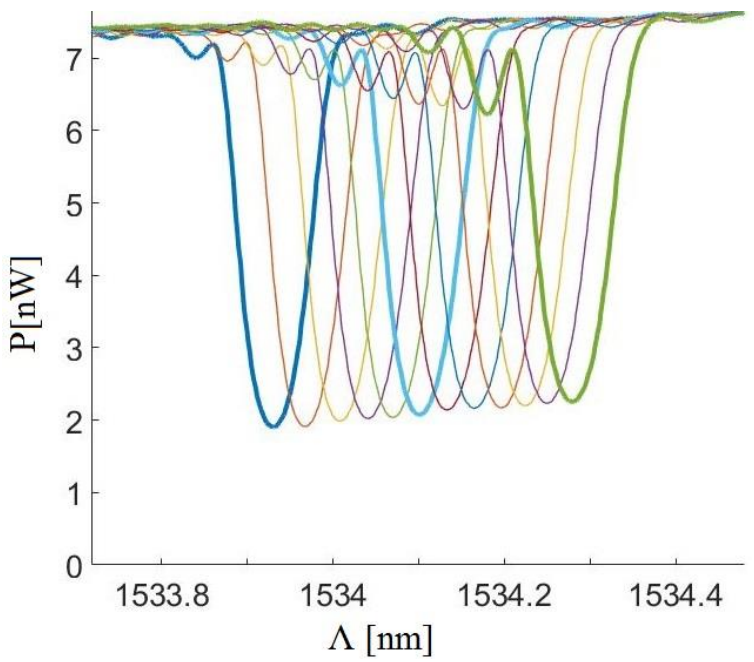

Fig. 4. Transmission characteristics obtained during the experimental research of the aluminum $10 \mathrm{~mm}^{2}$ cross-section sample

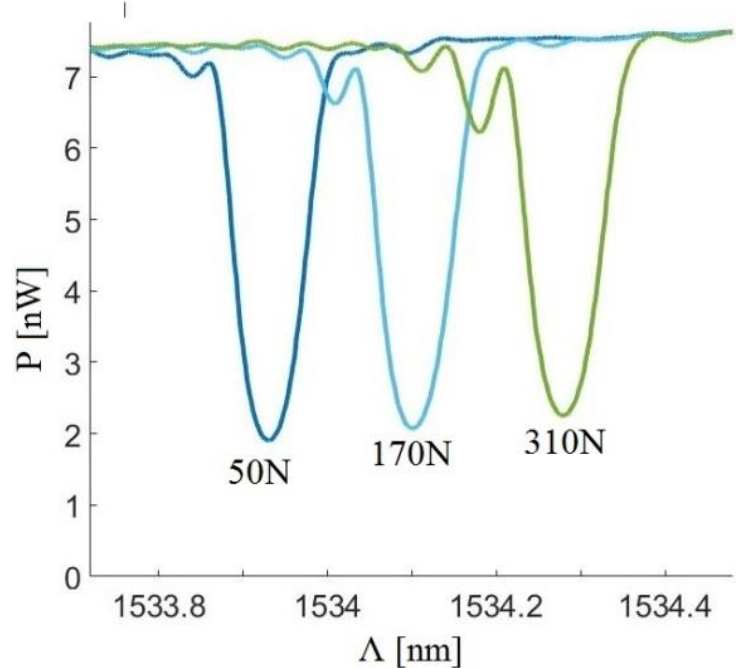

Fig. 5. Selected transmission characteristics obtained during the experimental research of the aluminum $10 \mathrm{~mm}^{2}$ cross-section sample

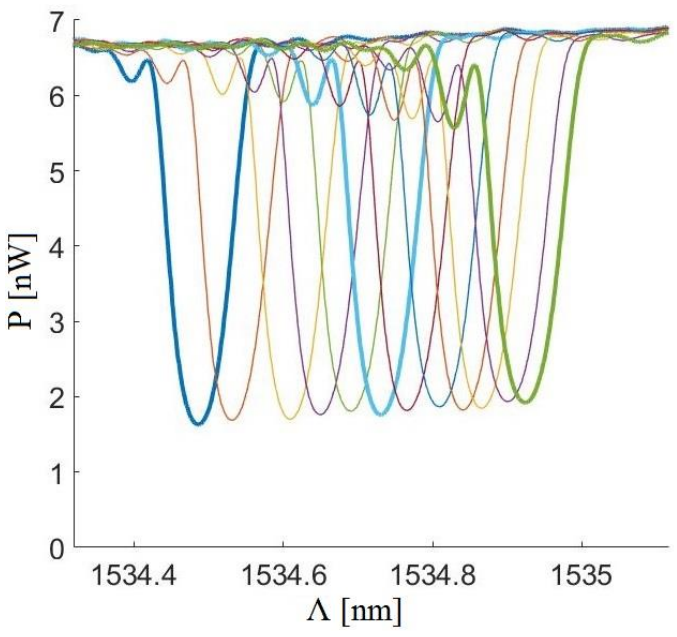

Fig. 6. Transmission characteristics obtained during the experimental research of the stainless steel $5 \mathrm{~mm}^{2}$ cross-section sample

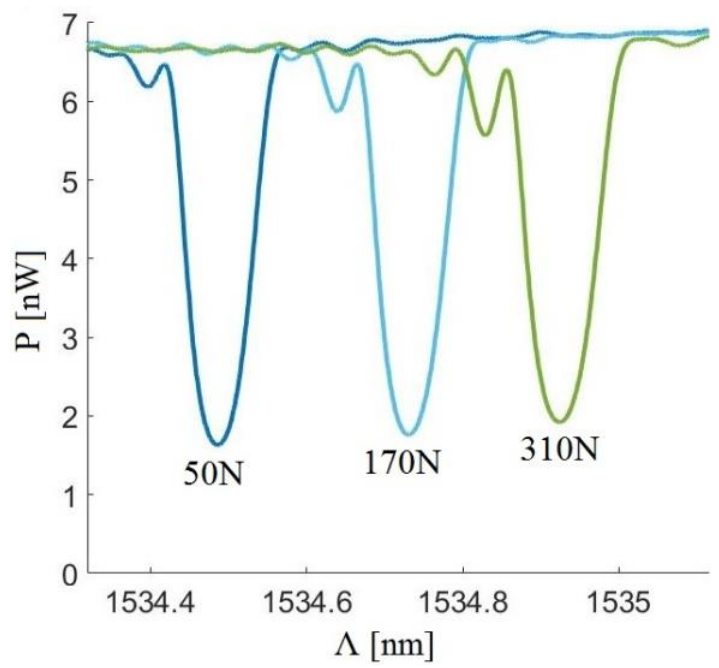

Fig. 7. Selected transmission characteristics obtained during the experimental research of the stainless steel $5 \mathrm{~mm}^{2}$ cross-section sample 


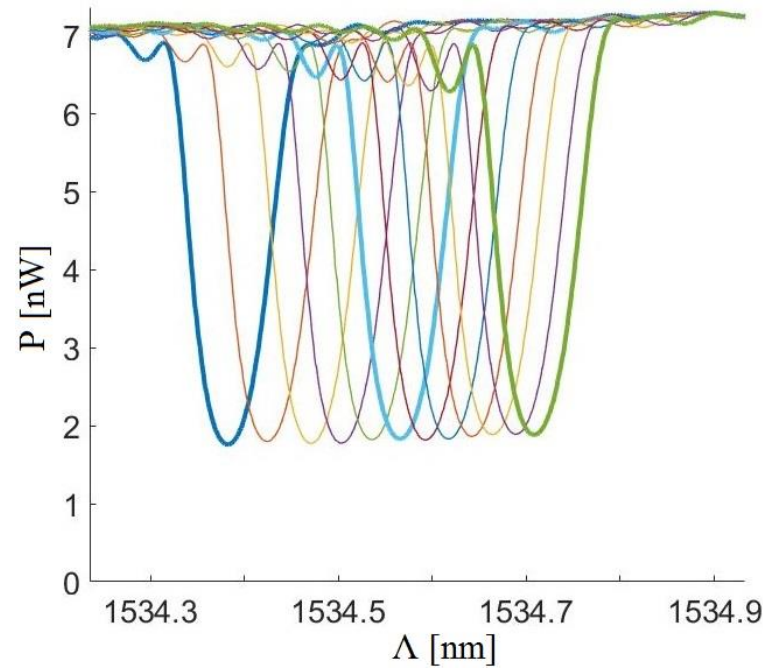

Fig. 8. Transmission characteristics obtained during the experimental research of the stainless steel $10 \mathrm{~mm}^{2}$ cross-section sample

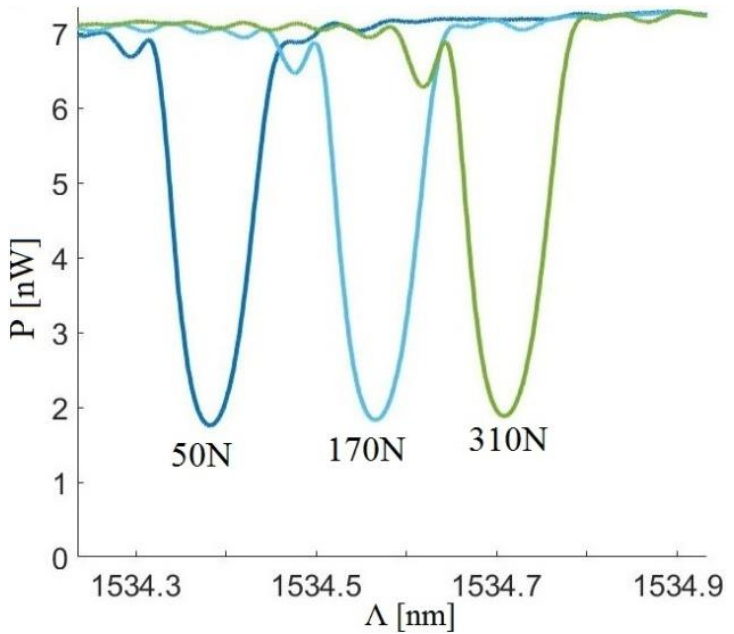

Fig. 9. Selected transmission characteristics obtained during the experimental research of the stainless steel $10 \mathrm{~mm}^{2}$ cross-section sample

\section{Results analysis}

Analyzing the results of tests on the elongation of stainless steel and aluminum samples using FBG and the adhesive method, we can conclude that one of the main reasons for the formation of side bands is the binder connecting the sensor with the sample. Shrinkage may occur in the adhesive structure during the drying process. This phenomenon directly affects the fiber embedded in it, by changing the geometry of the glued area and the occurrence of tensions in the area of the fiber Bragg grating causing deformation of the transmission spectrum.

Another feature affecting at working of the adhesive during the stretching process is its longitudinal elasticity described by Young's modulus. If the Young's modulus of the tested material significantly differs from the Young's modulus of the adhesive used to connect the sample with the sensor, it may affect the FBG stress reading. The adhesive with a much smaller modulus of elasticity than the sample module will absorb a large part of the elongation in its structure without transferring it to the fiber Bragg grating. On the other hand, the adhesive with a much larger Young's modulus than the sample module will cause local stiffening of the tested structure, and when tension is applied, it may crack causing damage to the sensor. During the preparation of the adhesive in the laboratory, it was noticed that in the process of mixing the components of the adhesive, air bubbles get into its structure. The use of an adhesive prepared in this way introduces discontinuities in its structure, which, depending on the amount and size of air bubbles, affect the adhesive's physical properties and its ability to transfer stress. Heating the adhesive, e.g. with a heat gun, while mixing it, significantly reduces the number of bubbles that flow out and break. It should be noted that most twocomponent adhesives should be mixed for the same volume rather than weight proportions.

Based on the research described in the literature, the phenomenon of glue crawling under the influence of temperature can be distinguished $[1,2]$, however, the research in the scope of the presented topic was carried out at a constant laboratory temperature and therefore this phenomenon did not occur.

Another significant element of the method of assembling the fiber Bragg grating to the tested element may be the method of attaching it to the tested place. In the above tests, the method of completely embedding the measuring transducer in glue was used. This method allows the fiber to be protected against external mechanical and chemical factors., This method also has a disadvantage, which is the difficulty of maintaining defined thickness of the adhesive pad between the fiber embedded in the adhesive and the element being tested. Another method of attaching a fiber Bragg grating to the tested element is spot gluing of the fiber. This method to some extent eliminates the effect of glue contraction during drying on the batch structure. The method also aims to generate uniform deformation over the entire FBG length to minimize wavelength dispersion.

Due to the nature of the research, the method of dipping the entire periodic structure in the adhesive was chosen. Tests of elements of mechanical structures at the destination are usually burdened with strong external factors that force sensor protection.

\section{Processing characteristics of the sensor}

Based on the received transmission characteristics, the processing characteristics were determined (Fig. 10-12). You can see that as the tensile force increases, full width at half maximum (FWHM) increases. In ideal conditions, when measuring stress, only the wavelength changes, while when measuring with an adhesive with a different Young's modulus coefficient than the material from which the FWHM sample is made, it increases with increasing stress value. This is another indicator of the selection of appropriate adhesive parameters.

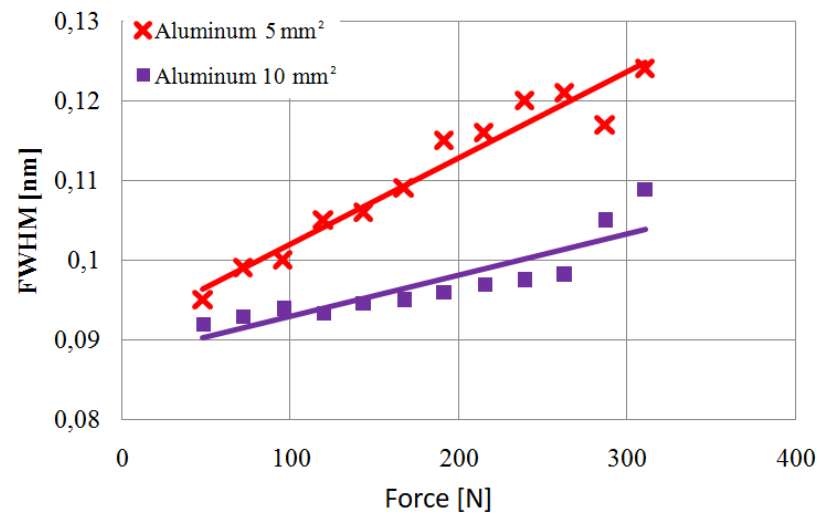

Fig. 10. The dependence of FWHM main module on the applied force for aluminum

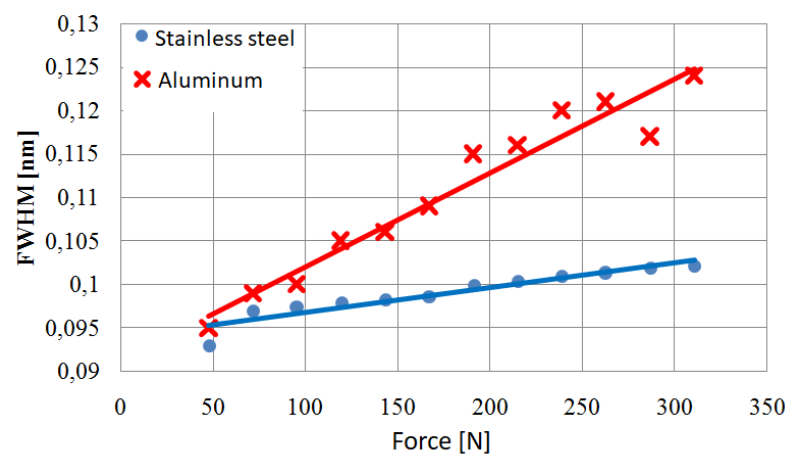

Fig. 11. The dependence of FWHM main module on the applied force for stainles steel and aluminum $5 \mathrm{~mm}^{2}$ 


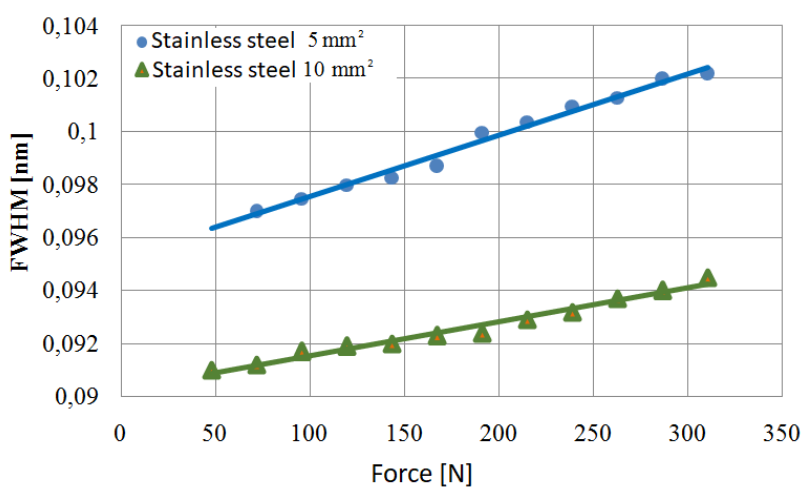

Fig. 12. The dependence of FWHM main module on the applied force for stainless steel

\section{Solution to the problem of sidebands}

Sidebands occurring mainly for the largest elongations (loads) of FBG are particularly unfavorable phenomena, hindering the interpretation of spectra. To eliminate them, it should be checked that all connectors in the measurement are clean and there are no bends in the fiber. For methods of gluing optical fiber, the side bands are lower than for methods of embedding FBG in glue, the applied compression during the drying of the glue will last less time.

How to evaluate a publication [6] side bands can also have a positive meaning, because they are information carriers and the extent of elongation.

\section{Reference linking}

Further research on adhesive joints will be focused on the appropriate selection of the Young's modulus of the adhesive for the tested element. It is also planned to use a new method of attaching the Bragg fiber grating to the examined site. The system was initially designed which combines the method of completely embedding the sensor in the glue and the spot gluing method (Fig. 13).

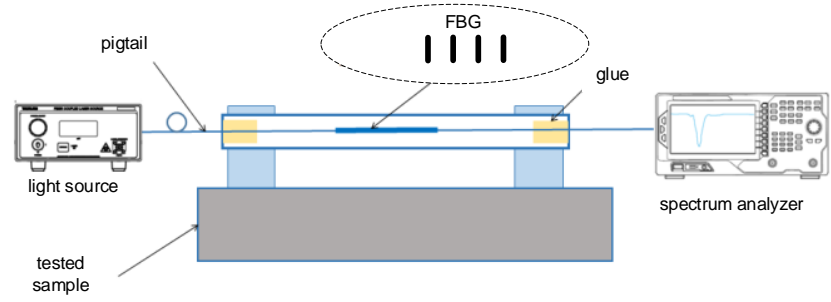

Fig. 13. Measuring head for FBG spot attachment

\section{M.Sc. Tomasz Zieliński \\ e-mail: tomasz.zielinski.1992@gmail.com}

Graduated from the Faculty of Electrical Engineering at Lublin University of Technology. Received his Master of Science degree in 2016. Title of Thesis: The analysis of sensory platform for use in the Internet of Things. Areas of interest: IoT, mobile systems in mechatronics, mobile system, fiber Bragg grating.
The proposed system is attached to the examined place in points enabling the generation of even deformation, read by FBG. The assembly of the optical measuring transducer is also made in points to minimize the effect of the adhesive shrinkage during its drying on the fiber Bragg grating. However, to protect the fiber optic inside the measuring system, a tube was used which, thanks to its properties, protects the measuring transducer against external factors. In principle, the tube used to protect the transducer will be made of a material with a smaller Young's modulus than the tested element so as not to introduce measurement interference.

The above arrangement will allow reuse of FBG for other heads, in contrast to the case of gluing the grating along its entire length. Although there are solvents for glues, their influence on the grating as well as subsequent gluing cause the formation of many side bands in the spectrum.

\section{Conclusion}

The above work presents the reason for the formation of transmission spectrum deformations obtained when measuring the elongation of structure elements using fiber Bragg grating. One of the reasons is the characteristics of the glue used to make the glue joint, its parameters and phenomena associated with shrinkage during the drying process. Another reason is the method of connecting FBG with the tested element, embedding the sensor in glue enhances the effect of glue shrinkage during drying. An important point of the work is to present a method that reduces the effect of glue on FBG.

\section{Bibliography}

[1] Berri P. C., Dalla Vedova M., Maggiore P.: Experimental comparison of Fiber Bragg Grating installation techniques for aerospace systems. MATEC Web of Conferences 304, 2019, 04012, [https://doi.org/10.1051/matecconf/201930404012].

[2] Hopf B., Koch A., Roths J.: Temperature Dependence of Glue-induced Birefringence in Surface-attached FBG Strain Sensors. Journal of Lightwave Technology 34(4) 1220-1227, [http://doi.org/10.1109/JLT.2015.2507621].

[3] Kisała P.: Detection of material defects with indirect method by determining the linear expansion with FBG sensor. Przeglad Elektrotechniczny 89(1A), 2013, 29-33.

[4] Kisała P.: Periodic fiber optic structures in optoelectronic sensors for measuring selected non-electrical quantities. Politechnika Lubelska, Lublin 2012.

[5] Wójcik W., Kisała P.: The application of inverse analysis in strain distribution recovery using the fibre Bragg grating sensors. Metrology and Measurement Systems 16(4), 2009, 649-660.

[6] Zychowicz Ł., Zieliński T., Skorupski K.: Defect detection in steel materials using sensors based on fiber Bragg gratings. Proc. of SPIE 11176, 2019, 1117619 .

\section{M.Sc. Lukasz Zychowicz \\ e-mail: lukas.zychowicz@gmail.com}

Lukasz Zychowicz is currently Ph.D. student in the Institute of Electronics and Information Technology of Lublin University of Technology (LUT). In 2016, he graduated from Mechatronics at LUT. His main scientific interests are fiber Bragg gratings.

http://orcid.org/0000-0001-6994-4120

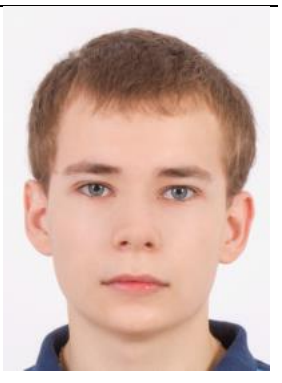

przyjęto do druku/accepted: 15.09 .2020 